\title{
Spinal Cord Decompression
}

National Cancer Institute

\section{Source}

National Cancer Institute. Spinal Cord Decompression. NCI Thesaurus. Code C124141.

Any of various procedures intended to relieve symptoms caused by pressure on the spinal cord and/or nerve roots. 